\title{
Effective Strategies for Second Language Vocabulary Acquisition
}

\author{
Yanqing SUN \\ School of Foreign Languages and Cultures, Beijing Wuzi University, Beijing, China
}

\begin{abstract}
This paper mainly introduces the concept of vocabulary knowledge and explores the strategies of improving second language vocabulary acquisition from the perspectives of learners and educators. It includes the concepts of vocabulary knowledge, the combination of intentional learning and incidental learning, and the influence of output activities on vocabulary acquisition.The concept of vocabulary knowledge in second language vocabulary acquisition is not only reflected in the number of words, but also in terms of quality; vocabulary acquisition should be the combination of intentional learning and incidental learning; learners should have the opportunity to use the language, and thus the output of the language plays an important role in language acquisition.
\end{abstract}

KEYWORD: Vocabulary knowledge; intentional learning; incidental learning; output activities.

\section{INTRODUCTION}

In Linguistics in Language Teaching, Wilkins discusses the importance of vocabulary in communication, "Without grammar, little can be conveyed; without vocabulary, nothing can be conveyed. (Wilkins, 1972: 80)." Vocabulary is the basic material of language. Without vocabulary, people cannot communicate freely. The mastery of vocabulary impacts the development of listening, speaking, reading and writing. The formation and development of students' language ability cannot be separated from the accumulation of vocabulary. Therefore, the issue of improving the effect of second language vocabulary acquisition has become an important research subject.

\section{CONCEPT OF VOCABULARY KNOWLEDGE}

The concept of vocabulary knowledge in second language vocabulary acquisition is not only reflected in the number of words, but also in terms of quality. The way of enlarging learners' vocabulary without considering the application of vocabulary knowledge is invalid.

"Vocabulary acquisition is the recitation of words and the increase of vocabulary", a majority of people hold this idea. In fact, vocabulary acquisition is based on the mastery of pronunciation, spelling, and word meaning, and then goes deep into the language domain, collocation, and other grammatical features of learning. How to definite the mastery of vocabulary, Cronbach (1942:204) gives a reasonable and accurate definition. He explains, "What is called "understanding a word'," he says, "to understand a word" refers to the learner's ability to identify and understand the vocabulary in the following five kinds of behavior:

1) Classification of target word (being able to define the target word)

2) Use of the target word (select the target word for the appropriate usage)

3) Width of the target word knowledge (can tell different meanings of target word)

4) Exact knowledge of the target word (can use exactly the target word in all possible occasions)

5) Associative meaning of the target word (can creatively use the target words)

Accordingly, vocabulary acquisition is by no means a simple process. Fries summarizes the reasons of oversimplifying the problem of vocabulary in foreign language teaching in three aspects: 1 Believing that vocabulary in different languages have accurate corresponding word; 2 Thinking that a word has only one meaning; 3 Thinking that every word has a basic meaning or the real meaning. Other meanings are metaphorical meanings or do not conform to common usage (Stern, 1983: 45). 
The specific context of learning can help us to understand and use the words accurately. We should not only grasp the concept of lexical meaning, but also be familiar with its connotation meaning and cultural significance of the information conveyed. Furthermore, the vocabulary is not isolated. It will have certain relations with other words, as synonyms, antonyms, and derivatives. As a result, vocabulary learning should be divergent, with the mastery of relative vocabulary, and with the collocation of the common words. It is important to note the interpretation of the teachers on the meaning of the vocabulary. Target language should be used to avoid the semantic error from the explanation of the mother language.

Vocabulary acquisition is a gradual process. Researchers concluded the five stages of vocabulary knowledge development (put forward by Paribakht \& Wesche in 1993, improved by Wesche and Paribakht in 1996):

1) I've never seen the word;

2) I've seen it before, but I don't know the meaning of the word;

3) I've seen the word, I think the meaning of the word is...; (give a synonym or translate the word)

4) I know the word. The meaning of the word is ; (give a synonym or translate the word)

5) I use the word to make a sentence.

Thus it can be seen that vocabulary acquisition is a process of development from identification to use.

\section{THE COMBINATION OF INTENTIONAL LEARNING AND INCIDENTAL LEARNING ON VOCABULARY ACQUISITION}

There are two ways to learn a language. One is intentional learning and another is incidental learning. Intentional learning language usually refers to reciting word purposefully, practicing grammar and reading drills. Incidental learning refers to language learning in reading, listening, speaking and film appreciation activities inadvertently. Vocabulary acquisition should be the combination of intentional learning and incidental learning.

Intentional learning is certainly effective, but it can't reach the requirement of a large number of vocabulary accumulations. Incidental learning can be complement, especially reading. How can we effectively learn vocabulary from short-term memory to long-term memory? Cognitive psychology researchers from the perspective of psychological linguistics and cognitive linguistics confirmed that the learners' reading on various chapters mainly accumulates vocabulary acquisition. Linguists also believe that most of the second language vocabulary is accidentally learned in the reading process.
Reading is one of the main ways on vocabulary acquisition for second language learners. Vocabulary sourced from listening and speaking is fleeting. In reading, learners can have sufficient time to pay attention to the context, speculation, and can be confirmed by the dictionary. Confirmation by dictionary is a valuable cognitive strategy for vocabulary acquisition. The combination of speculation and looking up the dictionary can produce 50\% of memory (Ellis 1994, 1995 et. al). Those frequently used vocabulary, which can affect reading comprehension, will get more attention. A word in the context of repeated multiple chapters would naturally stimulate the formation, activation and deepens the impression in the brain. The key words for the statement even affect comprehension of discourse. In order to eliminate obstacles to reading, the readers will have a strong will to make sense of the words. In addition, learning vocabulary in the context of the chapter will helps learners to fully understand the semantics and learn to use. Learning on the basis of understanding helps vocabulary from short-term memory to long-term memory to finally become a member of the mastery vocabulary. The different chapters provide a variety of materials and colorful background to increase the interest in vocabulary acquisition, not so boring as simple recitation of words.

In incidental vocabulary acquisition, the external and internal factors influence the effect of the reading and vocabulary acquisition. External factors include chapters' context, reading tasks, reading environment, and reading time; internal factors refer to individual differences in language learners, such as vocabulary knowledge, learning strategies, and learning motivation.

The difference between intentional learning and incidental learning lies in the different attention. In the former, teachers usually give the intention to students on vocabulary. In the latter occasion, learners focus on understanding the meaning of the chapter, and spontaneously pay attention to new words and learn new words.

Now that the intentional learning and incidental vocabulary learning can help learners to improve vocabulary knowledge, then choosing the teaching vocabulary and arranging the reading task is particularly critical.

\section{INFLUENCE OF OUTPUT ACTIVITIES ON VOCABULARY ACQUISITION}

The activities of seeing and hearing are imported, and speaking and writing belong to the output activities. In the experiments, Ellis and He (1999) found that the test result on vocabulary recognition and vocabulary output for the students attending output activities is much higher than the students 
attending imported activities. Swain proposed language output hypothesis that language input is necessary, but not sufficient condition for achieving language acquisition. To achieve a higher level of foreign language learners, comprehensible input alone is not enough. Learners also need comprehensible output. Students need to be required to make full use of existing language resources to think for the language to be output and to make it more appropriate, more accurate and easier to understand. Swain's output hypothesis points out that second language acquisition must have two-way communication activities. Simple language input on language acquisition is insufficient, learners should have the opportunity to use the language, and thus the output of the language plays an important role in language acquisition.

For classroom instruction on vocabulary, teachers should fully realize the importance of output activities in vocabulary acquisition. For some common core vocabulary, students are required to understand the words. At the same time, teachers should also require students to learn how to use properly in conversation and writing. To achieve this goal, we can't just stop at understanding based on input activities, we should also ask the students to carry out some output $t$ activities of the target words.

The main reason for the inappropriate use of vocabulary is in the lack of language training. Teachers exercise language input in the classroom and give the students few chance to practice. In this way, the teachers' feedback on students' mistakes are also very casual. Can the words be correctly and accurately used after understanding the meaning of words? We found that in the process of teaching it is obviously not so simple. In oral and written practice the following inappropriateness often occurs, such as speech, type of writing, context, collocation, and expressive habits. That is to say, the output activities will expose the difficulties and problems of the learners. We need to arouse cognitive activity, to correct and avoid the mistakes of using wrong vocabulary. At the same time, the right vocabulary can be consolidated.

Teachers should create a simulation context to help learners to activate the input information and the inputs into the outputs. It is vital to improve the ability of learners' language output. Therefore, teachers provide the necessary environment to acquire language forms and produce language meaning, let the students interested in the topic and subject given, and then be willing to participate in oral and written output activities, and be prepared for it. Oral practice can be used in a group dialogue, debate, role-playing, and other forms in the pleasant, relaxed atmosphere to improve the ability of thinking, using and improving language communication. In this process, teachers should focus on students' output contents by encouraging them to express and by giving appropriate correction. The teachers should also be careful for not damaging the continuity of the communicative atmosphere and communication. Output written exercises can be done by arranging writing tasks.

In vocabulary acquisition, the learners' attention should be increased. Learners pay attention to the words to conduct effective information processing. Learner's output activities not only convey meaning, but also integrate language form project into the path for intermediary language system. The reasonable allocation of attention resources during cognitive activity is the prerequisite of the output. In order to improve the effect of output activity, teachers should design output tasks and projects in advance. In the process of output activity, some forms of incidental learning ways guide the learners to learn in the full attention of the project. This incidental learning ways can help the learner's learning efficiency. For example, students must use specified vocabulary in repeating text or in writing exercises.

\section{CONCLUSION}

In summary, the second language vocabulary is related to the overall level of language for the learners. In order to improve the effect of vocabulary acquisition, the learners should understand the concept of vocabulary first and pay attention to the acquisition strategy, then combine the intentional learning and incidental learning in vocabulary acquisition. According to the influence of output activities on vocabulary acquisition, teachers should arrange the learning tasks in teaching to train the students in oral and written expression for the improving of communication skills.

\section{REFERENCES}

[1] Cronbach, J. 1942.An analysis of Techniques for diagnostic vocabulary testing. Journal of Educational Research 36,206-217.

[2] Dickinson, L. 1990. Self-instruction in Language Learning. Cambridge

[3] University Press. Dickinson, L.1987. Self-instruction in Language Learning. Cambridge University Press.

[4] Ellis, G. and B. Sinclair. 1987. Helping learners discover their learning styles. Presses Universitaires de Nancy.

[5] Ellis, G. and B. Sinclair.1989. Learning to Learn English: A course in Learner Training. Cambridge University Press.

[6] Ellis, N. 1994. Vocabulary acquisition: The implicit ins and outs of explicit cognitive mediation. Academic Press, 211-282.

[7] Gardner,R.C. and W.Lambert.1972. Attitudes and Motivation in Second Language Learning. Newbury House Publishers.

[8] Harmer, J. 1991. The Practice of English Language Teaching. Longman. 
[9] Holec, H.1981.Autonomy and Foreign Language Learning. Pergamon Press.

[10] Holic, H. 1979. Autonomy and Foreign Language Learning. Council of Europe.

[11] Krashen, S. 1981. Second Language Acquisition and Second Language Learning. Oxford: Pergamon Press.

[12] Krashen, S. 1982. Principles and practice in second language acquisition. Oxford: Pergamon Press.

[13] Krashen, S. and Terrell, T. 1983. The natural approach: Language acquisition in the classroom. Oxford: Pergamon Press.

[14] Krashen, S. 1985. The Input Hypothesis: Issues and implications. New York: Longman.

[15] Krashen, S. 1989. We acquire vocabulary and spelling by reading: Additional evidence for the input hypothesis. Modern Language Journal, 73, 440-464.

[16] Littlewood, W. 1981.Communicative Language Teaching. Cambridge University Press.
[17] Oxford, R.1990. Language Learning Strategies. Newbury House.

[18] Paribakht, S. and Wesche, M.1993.Reading comprehension and second language development in a comprehension-based ESL program. TESL Canada Journal 11, 9-29.

[19] Stern, H.1983.FundamentalConcepts of Language Teaching Oxford. Oxford University Press.

[20] Underwood, M.1989.Teaching Listening. Longman.

[21] Wallace,M.1993. Training Foreign Language Teachers: A Reflective Approach. Cambridge University Press.

[22] Wilkins, D. 1972. Linguistics in language teaching London. Edward Arnold.

[23] Qianlong Wu (QL, Wu). 2000. Second Language Acquisition Process

[24] Psychological Analysis. Foreign Language Teaching and Research4, 290-295. 